Platskamp, specialnummer av

Arkiv. Tidskrift för sambällsanalys, nr 9 (2018)

\title{
Stå upp för orten. Ungdomar, utanförskap och förortsdrömmar
}

\author{
Magnus Dahlstedt \& James Frempong
}

SAMMANDRAG: Magnus Dahlstedt och James Frempongs artikel handlar om ungdomar i "Orten", ett förortsområde som under de senaste åren varit föremål för omfattande negativ uppmärksamhet i offentlig debatt. Med utgångspunkt i en diskurspsykologisk ansats är syftet att analysera ungdomarnas tolkningar av sin tillvaro och sitt identitetsskapande i Orten, i relation till det omgivande samhällets förväntningar och tolkningar - om dem och om Orten. Analysen visar att ungdomarnas berättelser om tillvaron i Orten här och nu tar form som en kontrastverkan till omgivningens dominerande berättelser om "förorten". Orten framträder som en plats där ungdomarna känner sig hemmahörande. I berättelserna om framtiden är det huvudsakligen individuella scenarier riktade mot Orten som framträder, medan scenarier som bygger på kollektiv handling riktade mot världen utanför lyser med sin frånvaro. Sensmoralen som framträder är att förändring förutsätter att Ortens ungdomar tar eget ansvar och står upp för sig själva.

NYCKELORD: exkludering; stigmatisering; ungdomar; förorten; tolkningsrepertoar; diskurs.

PUBLICERINGSHISTORIK: Originalpublicering.

MAGNUS DAHLSTEDT är professor i socialt arbete vid Linköpings universitet.

E-POSTADRESS: magnus.dahlstedt@liu.se

JAMES FREMPONG är fil.kand. i samhälls- och kulturanalys och verksam vid Byrån mot diskriminering i Östergötland.

E-POSTADRESS: james.frempong@diskriminering.se

FÖRSLAG PÅ KÄLLANGIVELSE:

Dahlstedt, Magnus \& James Frempong (2018) "Stå upp för orten. Ungdomar, utanförskap och förortsdrömmar", i Platskamp, specialnummer av Arkiv. Tidskrift för samhällsanalys, nr 9, s. 27-51.

DoI: https://doi.org/I0.13068/2000-6217.9.I

(C) Författarna/Arkiv förlag \& tidskrift 2018 (publicerad 28 maj 20I8)

Artikeln distribueras enligt en upphovsrättslicens från Creative Commons:

Erkännande-Ickekommersiell-IngaBearbetningar 3.0 Unported, som medger fri ickekommersiell användning och spridning i oförändrat skick så länge källan anges. 
Arkiv. Tidskrift för samhällsanalys är en sakkunniggranskad vetenskaplig tidskrift för samhällsvetenskap och historia. Samtliga artiklar publiceras fritt tillgängliga på:

$$
\text { www.tidskriftenarkiv.se }
$$

Beständig länk, DOI: https://doi.org/IO.I3068/2000-62I7

Den här artikeln finns tillgänglig i följande format:

PDF: via beständig länk, DOI: https://doi.org/IO.I3068/2000-62I7.9.I

TRYCK: ingår i bokutgåva av numret, ISBN: 978 9I 79243159

Grafisk utformning och sidnumrering är identisk i pdf och tryck.

Samtliga artiklar i nr 9 (2018), Platskamp, nås via beständig länk, DOI: https://doi.org/I0.I3068/2000-6217.9

Redaktion för nUmret: Magnus Dahlstedt, Lisa Kings \& Nazem Tahvilzadeh

Arkiv. Tidskrift för sambällsanalys

ISSN: 2000-62I7 (för elektronisk resurs)

ISSN: 2000-6225 (för tryckta nummer)

ges ut av

Stiftelsen Arkiv för främjande och spridning av samhällsvetenskaplig och historisk forskning

genom

Arkiv förlag \& tidskrift

Box 1559

SE-22I OI Lund

BESÖK: L Gråbrödersg 3 c, ipg

TEL: 046-I3 3920

ARKIV FÖRLAG: arkiv@arkiv.nu·www.arkiv.nu

TIDSKRIFTEN ARKIV: red@tidskriftenarkiv.se.www.tidskriftenarkiv.se

ANSVARIg UTGIVARE \& CHEFREDAKTÖR: Sven Hort

AdMinistrativ Redaktör: David Lindberg

Redaktörer: Paavo Bergman, Per Dannefjord, Lisa Kings,

Zhanna Kravchenko, Anna-Maria Sarstrand Marekovic 


\section{Stå upp för orten. Ungdomar, utanförskap och förortsdrömmar}

\section{MAGNUS DAHLSTEDT \& JAMES FREMPONG}

... tanken är skapande och i varje ögonblick skapar vi framtiden med våra tankar och handlingar.

Dogge Doggelito

\section{Inledning}

Denna artikel handlar om ungdomar som lever i ett förortsområde i en av landets större städer, låt oss kalla området Orten. Artikeln kretsar närmare bestämt kring ungdomars sätt att se på och navigera bland omgivningens förståelser om dem och om Orten som plats. Orten är ett av de områden som under de senaste åren varit föremål för omfattande - mestadels negativ - uppmärksamhet i offentlig debatt, inte minst till följd av sociala spänningar och oroligheter som bland annat har involverat ungdomar bosatta i Orten. Med utgångspunkt i en diskurspsykologisk ansats är syftet med artikeln att analysera ungdomars tolkningar av sin tillvaro och sitt identitetsskapande i Orten, i relation till det omgivande samhällets förväntningar och tolkningar - om dem och om Orten. Hur ser ungdomarna på och navigerar bland omgivningens förståelser om dem och om Orten som plats? På vilket sätt formar dessa förståelser ungdomars syn på sin tillvaro och sin tillhörighet till Orten - i dag och i framtiden? Vilka diskursiva resurser använder sig ungdomarna av i sitt berättande om Orten i dag och i framtiden? 
Denna artikel presenterar inledningsvis en kort kontext kring ungdomar och den svenska förorten. Därefter skisseras den analytiska ansats som vägleder analysen samt det empiriska material som analysen grundas på. Med avstamp i denna analytiska ansats presenteras därefter huvudlinjerna i vår analys av det empiriska materialet, i det första avsnittet med fokus på ungdomarnas berättelser om samtiden och omgivningens föreställningar om den otrygga förorten, i det andra avsnittet med fokus på ungdomarnas berättelser om framtiden och de olika banor som ungdomarna ser framför sig inför framtiden. Avslutningsvis sätts de huvudsakliga resultat som presenterats in i det samtida politiska landskapet och diskuteras i relation till några av den polariserade stadens framtida utmaningar.

\section{Miljonprogrammet och diskursen om utanförskap}

Det svenska storstadslandskapet är, och har länge varit, påtagligt skiktat längs socioekonomiska och etnokulturella linjer. En alltmer alarmerande situation av segregation och polarisering i såväl större som mindre städer är en fråga som alltsedan 1990-talet ägnats stor uppmärksamhet i både akademin och den offentliga debatten (Tedros 2008). I blickfånget har inte sällan de områden som byggdes under 1970-talets så kallade miljonprogram stått. Med tiden har miljonprogrammets områden till stor del kommit att domineras av resurssvaga hushåll med utländsk bakgrund. Inte minst sedan 1990-talets krisår har polariseringen mellan olika områden i städerna kraftigt tilltagit - med alltmer ojämlika levnadsvillkor (Andersson m.fl. 2009; Scarpa 2015).

I miljonprogrammets områden bidrar rumslig åtskillnad, marginalisering på arbetsmarknaden och territoriell stigmatisering sammantaget till sociala och ekonomiska men även utbildningsmässiga ojämlikheter som drabbar inte minst barn och ungdomar (Bunar 2009). I dessa områden tenderar exempelvis skolor att stigmatiseras och få dåligt rykte, vilket i många fall resulterat i en utflyttning av elever till mer statusmässigt åtråvärda skolor (Ambrose 20I6). Eftersom de elever som väljer att stanna kvar generellt är från familjer med mindre socialt, ekonomiskt och kulturellt kapital än de som flyttar så tenderar skolresultaten att för- 
sämras. Som ett resultat av detta tenderar skolornas rykte i sin tur att försämras ytterligare, och så även deras förutsättningar att hävda sig i konkurrensen på skolmarknaden (Kallstenius 20I0).

Den offentliga berättelsen om miljonprogrammet har alltsedan I970talet varit en berättelse om "annorlundahet" (Ristilammi 1994). Miljonprogrammets områden har i allt väsentligt fătt representera det "annorlunda”, något som det övriga svenska samhället har speglat sig i. Dessa områden har därmed utgjort ett slags fantasilandskap, som har fått en bestämd svensk normalitet att framträda (Ericsson 2007). Berättelsen om miljonprogrammet har fokuserat på konflikter, avvikelser och problem, såsom kulturkrockar, gängrivalitet, droger, dåliga skolprestationer och skadegörelse (jfr Ålund 1997; Pripp 2002; Lindbäck \& Sernhede 20IO).

Miljonprogrammets annorlundahet har över tid getts olika innebörd (se vidare Ristilammi 1994; Dahlstedt 2005). På 1970-talet beskrevs miljonprogrammet som annorlunda först och främst i socialt hänseende. Områdena sågs som annorlunda därför att de som bodde där var arbetarklass, lågutbildade och i en del fall missbrukare. Senare ändrade berättelsen gradvis karaktär och kom alltmer att ta fasta på miljonprogrammet som annorlunda i etnokulturellt hänseende. I takt med att allt fler av de boende hade sina rötter $\mathrm{i}$ andra delar av världen kom områdena att beskrivas som annorlunda därför att många av de som bodde där var "invandrare" och därmed mer eller mindre "kulturellt annorlunda". Många av de konflikter och problem som tidigare tolkats i sociala termer tolkades nu i ljuset av kulturskillnad och invandrarskap. Enligt hotbilden sades miljonprogrammet med tiden riskera att utvecklas till ett slags parallellt samhälle med egna regler, normer och sociala koder, mer eller mindre frikopplade från det övriga svenska samhället.

Denna framställning av miljonprogrammet som ett samhälle vid sidan av har levt kvar, även om den förändrats. I 2000-talets offentliga debatt beskrivs miljonprogrammets områden fortfarande som annorlunda, men de betecknas inte längre som "invandrarförorter" utan som "utanförskapsområden" (Davidsson 20IO; Dahlstedt 20I5). Den främsta konfliktlinjen i diskursen om utanförskapsområden är den mellan arbete och utanförskap - att ha eller att inte ha ett arbete (Dahlstedt 2009; 
Larsson 20I5). Utanförskap förstås dock inte bara som en ekonomisk fråga; det har även en sociokulturell, emotionell sida som kan relateras till de känslor av maktlöshet, utsatthet, alienation och misstro som utanförskapet framkallar (Davidsson 20IO). Miljonprogrammets områden beskrivs nu som annorlunda inte enbart därför att de boende är socialt eller etniskt annorlunda utan framför allt därför att de antas frammana särskilda värderingar vilka i sin tur förmodas ha ett slags självgenererande logik. När dessa värderingar väl har fått fotfäste uppges de ha sitt eget liv, och de riskerar att spridas och föras över från generation till generation (Stigendal 20i6).

Miljonprogrammets områden framstår därmed som ett slags antites till det som ses som normalt och önskvärt - i form av anpassningsförmåga, engagemang, initiativförmåga och anställningsbarhet (Dahlstedt 2015). När det gäller förortens unga så har de i den massmediala och politiska debatten tenderat att porträtteras som å ena sidan passiva, eftersom de sällan deltar i formella politiska och civilsamhälleliga sammanhang eller gör aktiva val, och å andra sidan som missriktat aktiva eftersom de ägnar sig åt olika slags ordningsstörande aktiviteter (Ekholm 20I6; Kings 20II).

Forskning har visat på hur ungdomar i miljonprogrammets områden i olika avseenden starkt påverkas av såväl rådande strukturella villkor som dominerande diskurser (Ålund 1997; Lalander 2009; Lundqvist 20ıо). Även om de unga själva inte känner igen eller accepterar de bilder som utmålas av dem och deras område, blir bilderna ändå en verklighet som de är tvungna att förhålla sig till - endera genom att identifiera sig eller att disidentifiera sig med den (jfr Andersson 2003; León Rosales 20IO). Utifrån rådande utanförskapsdiskurser lär sig de unga att se samhället som uppdelat i ett "inne" och ett "ute", ett "vi" och ett "de", där de själva tillhör kategorin "ute" och "de andra". När denna uppdelning blir en del av de ungas förståelse av sig själva kan den närmast beskrivas i termer av "symboliskt våld", en destruktiv kraft som bidrar till att upprätthålla hierarkier och ojämlikhet (Sernhede 20II). Samtidigt kan gränsdragningen mellan "inne" och "ute", "vi" och "de" bidra till att skapa en känsla av gemenskap bland de unga som tillskrivs en position i "utanförskap", där det snarast framstår som otryggt och ovälkommet 
för de unga att röra sig i andra delar av staden än i deras "eget" område (Lindbäck \& Sernhede 20IO).

Till skillnad från de beskrivningar som ges med utgångspunkt i den dominerande utanförskapsdiskursen har forskning dock pekat på att ungdomar inte är några passiva eller viljelösa offer, utan att de snarare utvecklar en bred repertoar av strategier när det gäller att beskriva, hantera och förhandla med rådande villkor och rådande diskurser (León Rosales 20Io; Dahlstedt m.fl. 20I6). För ungdomar utgör inte minst populärkulturen, - däribland hiphopen (Sernhede 2002; Sernhede \& Söderman 20Io) eller för den delen uttrycksformen poetry slam - en arena där det pågår en livaktig förhandling. Denna förhandling åskådliggör den stigmatisering och exkludering som drabbar de boende i förorten, och den ingjuter dessutom en känsla av stolthet över att leva och verka på platser som tillhör den svenska urbana geografins baksida (Sernhede 2002; Dahlstedt 2005).

En bit in på 2000-talet har en rad forskare pekat på en alltmer högljudd mobilisering av just unga i miljonprogramsförorter runt om i landet (jfr Schierup m.fl. 20I4; León Rosales \& Ålund 20I7). Det har här visats på hur avsaknaden av utrymmen för demokratiskt deltagande och reella möjligheter att göra sina röster hörda har skapat frustration bland ungdomar gentemot ett exkluderande svenskt samhälle. De senare årens oroligheter i form av stenkastning mot polis och utryckningsfordon har här lyfts fram som uttryck för en sådan frustration (jfr de los Reyes m.f. 20I4; Stigendal 2016). I relation till dessa oroligheter har frustrationen bland de unga samtidigt varit en grogrund för framväxten av en urban rättviserörelse. Även om förortsbaserade organisationer som Megafonen, Pantrarna och Hassela ungdomsrörelse fortfarande bara utgör en mindre del av det samlade civilsamhället så har de satt tydliga avtryck i samhällsdebatten - i protest mot stigmatisering, ojämlikhet och en accelererande nedrustning av välfärden (Kings 20I4; Schierup m.fl. 20I4; León Rosales \& Ålund 20I7). 


\section{Analytisk ansats}

Analysen tar avstamp i en diskursteoretisk tradition och närmare bestämt den så kallade diskurspsykologiska ansats som bland annat utvecklats av socialpsykologer som Michael Billig (1987), Margaret Wetherell och Jonathan Potter (I988, I992). I fokus för denna ansats står människors sätt att förstå och skapa mening om sig själva och om samhället, det vill säga konstruktionen av identitet och verklighet. Ansatsen utvecklades som en reaktion mot det individcentrerade kognitiva paradigm som under lång tid dominerat socialpsykologin, där socialpsykologiska fenomen betraktats som kognitiva processer - med fokus på perception, tänkande och attityder (se Gergen 1985; Edwards \& Potter 1992; Billig 1991).

Till skillnad från detta kognitiva paradigm förstås individers identiteter, attityder och känslor som konstituerade genom diskursiva praktiker snarare än som ett resultat av individuella, kognitiva processer (Edwards \& Potter 1992). Diskurs ses här som det medel genom vilket både jaget och världen artikuleras. Utifrån denna ansats har uppmärksamhet ägnats åt de olika möjligheter som olika diskurser erbjuder människor när det gäller att skapa olika representationer av sig själva, världen och sitt handlande i världen (Wetherell \& Edley 20I4).

En viktig utgångspunkt för den diskurspsykologiska ansatsen är att människor inte är konsekventa när de beskriver sin omvärld. Över tid utvecklar människor snarare en mängd olika representationer av sin omvärld, beroende på det sammanhang där dessa beskrivningar görs. Även om ett och samma fenomen i skilda sammanhang kan beskrivas på en rad olika sätt så kan dessa skilda beskrivningar ändå bestå av en och samma uppsättning "förhållandevis internt konsistenta, sammanlänkade språkliga enheter, som vi kallar tolkningsrepertoarer [interpretative repertoires]" (Wetherell \& Potter 1988, s. I7I).

Tolkningsrepertoar är ett av diskurspsykologins nyckelbegrepp. När människor talar om något så gör de det med hjälp av de diskursiva resurser som gjorts tillgängliga för dem. Med begreppet tolkningsrepertoar avses den samlade uppsättning av diskursiva resurser som människor kan använda för att konstruera skilda versioner av verkligheten. Enkelt uttryckt skulle man kunna beskriva tolkningsrepertoarer som den språk- 
liga verktygslåda som människor använder för att tala om sig själva och om världen.

Repertoarer kan förstås som byggstenar som talare använder för att skapa versioner av handlingar, kognitiva processer och andra fenomen. Varje specifik repertoar skapas utifrån en begränsad uppsättning begrepp som används på ett specifikt stilistiskt och grammatiskt sätt. Dessa begrepp kan vanligtvis härledas till en eller flera nyckelmetaforer och förekomsten av en repertoar påvisas inte sällan av särskilda troper eller språkliga mönster. (Wetherell \& Potter I988, s. I72.)

Ett viktigt begreppspar relaterat till begreppet tolkningsrepertoar är subjektsposition och positionering, som används för att analysera hur människors identitetsskapande äger rum genom specifika diskursiva praktiker i specifika sammanhang. Begreppsparet avser närmare bestämt de specifika positioner som är möjliga för skilda subjekt att inta inom en bestämd tolkningsrepertoar och vilka specifika värden, egenskaper och förmågor som dessa subjekt tillskrivs - det vill säga hur skilda subjekt positioneras, i relation till andra subjekt (Wetherell 200I).

En diskurspsykologisk ansats kan bidra med viktig kunskap om hur ungdomar i Orten argumenterar kring den tillvaro de lever i, och om hur denna argumentation formas av det sammanhang de befinner sig i. Med utgångspunkt i en sådan ansats analyseras i artikeln fokusgruppsintervjuer med ungdomar boende i Orten. Vi ser denna typ av material som särskilt väl lämpat att analysera med hjälp av just diskurspsykologin som analytisk ansats (jfr Duits 2008; Jackson \& Hall 20I6; Nortio m.fl. 20I6). Materialet har nämligen skapats i och genom samtal och är därmed i hög grad präglat av samtalets dynamik. Materialet är också mångbottnat. Det finns inte en röst i intervjuerna, utan de inrymmer en mångfald av röster och utsagor som ständigt bryts mot varandra, där argument ständigt prövas och förändras efter samtalets gång. Enskilda utsagor och individuella ståndpunkter är härmed inte "färdiga" på förhand, utan de blir så att säga till vid själva intervjutillfället, där såväl övriga intervjuade som samtalsledare är med om att forma det som sägs. Intervjumaterialet kan därmed förstås och analyseras som en "gemensam produktion eller konstruktion av en meningsfull social värld" (Wetherell 2004: 23). 
Intervjuerna genomfördes under hösten 20I5. Ungdomarna var vid tiden då intervjuerna genomfördes i åldern I5 till I9. Deltagarna rekryterades med hjälp av snöbollsurval, genom kontakter förmedlade via skola, fritidsgård och lokala ideella föreningar. Urvalet av ungdomar gjordes med ambitionen att ge spridning med avseende på kön (Io killar och 6 tjejer) och bakgrund i olika delar av världen (I född i Sverige av infödda svenska föräldrar och Is födda utomlands eller i Sverige, av utrikes födda föräldrar, med bakgrund i olika delar av världen).

Sammanlagt genomfördes fyra fokusgruppsintervjuer. Ungdomarna intervjuades i grupper om 4 personer, vilket i litteraturen kring fokusgruppsintervjun och dess metodik brukar ses som ett rimligt antal deltagare för att skapa en produktiv samtalsdynamik vid intervjutillfället (jfr Morgan 1998; Wibeck 20I0). Samtliga intervjuer genomfördes av en av författarna (James Frempong). Fokusgruppsintervjuerna var semistrukturerade och följde en och samma intervjuguide, med ett tiotal öppna frågeområden som ungdomarna ombads diskutera och reflektera kring. Frågorna kretsade kring ungdomarnas erfarenheter av att bo och leva i Orten, med fokus på här och nu och framtiden. Samtliga intervjuer transkriberades ordagrant.

Med utgångspunkt i den analytiska ansats som presenterats ovan har fokusgruppsintervjuerna bearbetats och tolkats utifrån de berättelser om identitet och tillhörighet till Orten i dag och i framtiden som återkommer i intervjuerna. Dessa berättelser har analyserats utifrån de skilda diskursiva resurser som ungdomarna använder för att positionera sig själva och beskriva sin tillvaro i Orten - i form av utsagor, begrepp, kategoriseringar och metaforer. Vi har i vår analys inte haft för avsikt att identifiera vare sig ungdomarnas "sanna" identiteter eller den "reella" verkligheten i Orten, utan avsikten har snarare varit att identifiera återkommande diskursiva mönster i det som i ungdomarnas utsagor framträder som sant och reellt. Resultatet av analysen presenteras i det följande i två delar, en första med fokus på hur ungdomarna talar om sig själva och sina liv i Orten i dag och en andra med fokus på ungdomarnas berättelser om framtiden. 


\section{Förorten, samtiden och (o)tryggheten}

I samtliga fokusgruppssamtal finns en övergripande tolkningsrepertoar, bestående av en uppsättning beskrivningar och diskursiva resurser. Enligt denna tolkningsrepertoar berättar ungdomarna om sig själva och sina liv i Orten på ett bestämt sätt. Orten utgör ett hem, en familjär och trygg plats, där ungdomarna beskriver sig som omhändertagna och hemmahörande. Denna berättelse om Orten som hem tar i allt väsentligt form i ett slags ständigt motsatsförhållande till det som ungdomarna ser som omvärldens sätt att beskriva och förstå såväl Orten som andra mångetniska förortsområden runt om i landet. Denna ömsesidiga relation mellan ungdomarnas och omgivningens respektive berättelser om Orten framkommer exempelvis i följande sekvens, från en av fokusgruppsintervjuerna:

JAMES: Hur är det att bo i Orten?

AHMED: Det är skönt, man känner sig trygg för man är född och uppvuxen här.

EMIR: Man känner alla här runt omkring.

VEDAT: Alla fördomar, jag tycker det är lite överdrivet.

JAMES: Vad gör att ni känner er trygga?

AHMED: Vi är som en familj här, alla känner varandra.

JAMES: Hur ser ni på omvärldens uppfattningar?

EMIR: Alltså det kan ju hända att det händer grejer, men jag tycker det är överdrivet.

SELIM: Då händer det grejer, men alltså media kryddar på.

I sekvensen ovan åskådliggörs den tolkningsrepertoar enligt vilken ungdomarna samstämmigt identifierar sig med Orten, ser den som sitt hem. Ungdomarna beskriver Orten som en trygg plats, till skillnad från omvärldens beskrivningar av Orten som en otrygghetens plats. Den känsla av trygghet som de uttrycker är knuten till att ungdomarna är födda och uppvuxna i området. De hör med andra ord hemma i Orten. I sekvensen fångas detta hemmahörande träffande i metaforen familj. Liksom andra metaforer är metaforen familj en kraftfull diskursiv resurs. Den gör det möjligt att gestalta Orten som en plats där de boende tillhör en tät social gemenskap, där alla känner varandra. Utifrån denna metaforik positionerar sig ungdomarna som del av förortens familjegemenskap: "Vi är som en familj här". 
Men samstämmigheten i berättelsen om Orten som en trygg plats är inte helt utan friktioner. Samtidigt som Orten beskrivs som trygg påtalar ungdomarna att det visst "händer grejer" även i denna miljö. Men ungdomarna menar att sådana händelser förstoras upp, inte minst av media. De anser att beskrivningen av Orten som en otrygg plats i mångt och mycket är överdriven. Den tolkningsrepertoar enligt vilken Orten beskrivs som en trygg familjegemenskap är med andra ord formad utifrån en omgivande berättelse om Orten, som ungdomarna använder som en diskursiv resurs i sitt eget berättande om världen.

En tematik som ständigt återkommer i intervjuerna är medias roll när det gäller att framställa Orten som en otrygg plats i stadens periferi:

DIMEN: Alltså, när jag tittar på tv, alltså media så förklarar de Orten i sig som ett ghetto ... det är verkligen hemskt ... de tar de här bilderna och tar foton och filmar den sunkigaste platsen, alla har sunkiga platser överallt i hela Sverige, men om de verkligen kommer och verkligen tittar i Orten, i Ortens skolor, områden, överallt, då ser de att det är liksom inte gäng som förstör, det är liksom inte så, det finns överallt. Jag kan inte förneka att det absolut inte finns i Orten, för det gör det, men jag tycker att det är en underbar plats, såsom många andra ställen i Staden och i Sverige.

Återigen framträder en motsägelsefull bild av Orten - och återigen blir omgivningens och framför allt mediernas beskrivningar en diskursiv resurs som används för att gestalta den trygga Orten. För Dimen är Orten en "underbar plats" som inte alls överensstämmer med den bild som målas upp exempelvis i media, "ett ghetto". Visst förekommer det oroligheter också i Orten, men inte alls i den omfattning som beskrivs i medierna.

I omgivningens ögon förstås Orten som en otrygg och annorlunda plats, men Dimen beskriver snarare Orten som helt normal. Denna omkastning blir möjlig för honom genom att han använder sig av två diskursiva resurser. Den ena är jämförelsen med andra områden: "alla har sunkiga platser överallt i hela Sverige" och "såsom många andra ställen i Staden och i Sverige". Den andra är den egna erfarenheten av att röra sig på olika platser i Staden: ”Jag brukar hänga i Stadens centrum, för jag har många kompisar där. Men saken är den att jag inte känner mig lika trygg som jag gör här i Orten.” 
Argumentationslinjen går igen hos Siana, som också hon framhåller att det finns ett glapp mellan Orten som verklig plats och omgivningens fantasier om Orten:

SIANA: Det är så var man än går. I varje land finns det någon förort som är utsatt, som är allmänt, åk inte dit, det är farligt ... det är bara skitsnack. Det är mer mord i stan än vad det är här ... Alltså, jag tror inte de är medvetna om det, men de skadar oss egentligen.

Siana konstaterar inte bara att omgivningens föreställningar är felaktiga. Hon är påtagligt upprörd och säger emot dem: de är "bara skitsnack". Enligt henne är det till och med mer otryggt på andra platser. Orten beskrivs - än en gång - inte som annorlunda, utan precis lika problematisk som andra områden. Återigen fungerar jämförelsen som diskursiv resurs. "Det är mer mord i stan." För Siana handlar frågan dock inte bara om tillvaron i Orten - hon jämför även Orten med Orter i andra länder: varje land har nämligen sina egna Orter, det vill säga områden som pekas ut som särskilt farliga. I citatet understryker Siana dessutom att omgivningens föreställningar om den otrygga Orten inte bara handlar om ord, en tankegång som också återkommer i intervjuerna. Dessa föreställningar har även en rad högst påtagliga konsekvenser för dem som bor i området: "de skadar oss".

I intervjuerna underbyggs denna tankegång med hänvisningar till en rad personliga, vardagliga erfarenheter. Myner ger exempelvis några konkreta exempel på vilka slags konsekvenser omgivningens föreställningar om den otrygga Orten kan ha:

MYNER: Alltså det påverkas om du kollar till exempel om man ska köpa en bil och du ser försäkringen, hur den är. De kollar när du får jobb, de kollar mycket var du är bosatt. Allt blir dyrare på grund av fördomarna.

I en rad vardagliga situationer har hemmahörandet konsekvenser. Den sammantagna konsekvensen är - såsom den framträder i Myners beskrivning - tydlig: det är på olika sätt dyrare och svårare att bo i Orten än på andra platser. Hur det kommer sig framstår dock som otydligt i Myners resonemang. Bakom de processer som styr de negativa konsekvenserna kan vi urskilja ett diffust "de", som inte närmare definieras. 
För ungdomarna framstår det som självklart vilka "de" är. Det behöver inte artikuleras utan tillhör ungdomarnas sunda förnuft.

Konsekvenserna av omgivningens förväntningar är inte bara materiella. I det dagliga livet har förväntningarna också en rad konkreta sociala konsekvenser, inte minst när ungdomarna rör sig i andra delar av staden. I en längre sekvens från en av fokusgruppsintervjuerna får vi en inblick i hur dessa sociala konsekvenser fungerar:

JAMEs: Hur känns det att vara på platser som ni vanligtvis inte vistas på? Hur känns det för er?

SIANA: Man känner sig inte hemma.

Younes: Det är inte tryggt.

HAMID: Nej.

JAMES: Hur blir ni bemötta?

HAMID: Stelt.

SIANA: Det är jättestelt. Jag åkte till en finare stadsdel ... på bussen, du vet, jag var mig själv och redan där börjar folk kolla annorlunda på mig och vad gör hon på ett sådant här ställe? Man känner sig inte trygg. Här bryr sig ingen om vad du har på dig, så det är så där.

HAMID: Ja, det är också en stor del vad du har på dig, alltså vilka kläder du har på dig och så, så det är som Siana säger, de kollar alltid.

SIANA: De dömer dig på förhand. De vet inte ens vad du heter i efternamn och de dömer dig.

HAMID: När du går på klubb eller något sådant i stan ... det är alltid så här, ah, men ser du bra ut, då kommer du in. Har du någonting annat, blatteaktigt, då kommer du aldrig komma in. Det är alltid så.

YOUNEs: Det är precis som de säger, man känner sig utanför helt enkelt. Man vill inte vara en del av det egentligen.

SIANA: Och sedan finns det också de här som försöker göra allt för att passa in i samhället.

ÖVRIGA: Aa ...

SIANA: Alltså typ en blattebrud härifrån, som verkligen gör allt för att passa in, verkligen allt, trendigt uteställe och käka hit, börja gymnasiet i stan och försöker bli som dom, snobbarna, så du vet, det är jättemånga som försöker, men det hjälper inte.

Med hjälp av jämförelser och egna erfarenheter beskriver ungdomarna i denna sekvens återigen Orten som en trygg plats, i kontrast mot en otrygg omvärld där de inte hör hemma på samma sätt som de gör i Orten. Med utgångspunkt i tidigare erfarenheter beskriver de hur de inte känner sig hemma när de rör sig i andra områden: "man känner sig 
utanför helt enkelt”. De upplever sig som avvikande - i sitt sätt att klä sig, sitt utseende, sitt sätt att tala och bete sig. Av världen utanför Orten positioneras de som avvikande och utanför.

Denna position beskrivs i sekvensen ovan med hjälp av ordet "blatte", vanligtvis ett starkt nedsättande ord som av ungdomarna dock används som en diskursiv resurs när de ska beskriva sig själva. Exakt vad som åsyftas med just detta ordval framkommer inte riktigt. Det tycks snarare tas för givet som någonting självklart bland ungdomarna. Att vara "blatte" är att tillhöra Orten, alltså att ses som "annorlunda". "Blatte" blir härmed en diskursiv resurs som gör det möjligt att åskådliggöra omgivande diskurser om Orten som "annorlunda" och om ungdomarna som "dömda på förhand". Utifrån den beskrivning som görs tycks det inte spela någon roll hur ungdomarna beter sig. De kan försöka anpassa sig, bli som de, "snobbarna", "men det hjälper inte", de blir ändå betraktade som "de". Omvänt beskriver ungdomarna omgivningen på ett snarlikt sätt, som ett singulärt homogent kollektiv: "de".

\section{Förorten och drömmarna om framtiden}

Hitintills har vi uppehållit oss vid hur ungdomarna beskriver sig själva och sin tillvaro i Orten i dag och hur de i denna beskrivning framträder i en position som avvikande och utanför. Vilka olika sätt att tänka kring och gestalta framtiden är det då som framträder i ungdomarnas berättelser utifrån denna specifika tolkningsrepertoar för hur samtiden kan förstås? Liksom när det gäller ungdomarnas berättande om samtiden så finns det i deras berättande om framtiden en tämligen samstämmig tolkningsrepertoar. Enligt denna kan ungdomarna, eftersom de av omvärlden positioneras som avvikande och utanför, inte räkna med någon hjälp utifrån, utan de behöver stå upp för sig själva. Bland ungdomarna artikuleras därmed en samstämmig och stark vilja att på olika sätt utmana omvärldens föreställningar om dem själva och om Orten. I det följande ska vi presentera tre huvudsakliga sätt på vilka ungdomarna talar om framtiden och de scenarier som de uppfattar som möjliga när det gäller att skapa sin framtid: genom hopp och tro, politiskt och ideellt engagemang samt utbildning. 


\section{"Man lyckas om man vill" - om tro, hopp och vilja}

I ungdomarnas berättelser om framtiden finns en genomgående, stark vilja att förändra rådande villkor och föreställningar, att inte ge upp inför alla de svårigheter och utmaningar som de säger sig stå inför. Viljan att åstadkomma förändring framkommer tydligt i följande sekvens från en av intervjuerna:

SIANA: Alltså, det skadar oss men det gör oss starkare, det är väl typ, what doesn't kill you makes you stronger, typ så. Det är ju det. Vi är ju unga alltså, vi ser det här, vi vet.

HAMID: Alltså, vi har framtid.

SIANA: Precis, det är det, jag vet inte hur jag ska förklara, men vi kan ändra på det, vi kommer att ändra på det, vi ska ändra på det och vi är på väg att ändra på det, det är inte så att vi inte har börjat, vi har börjat för länge sen, hehe, men alltså, det handlar om att verkligen sätta ner foten och visa att det är så här, du vet, vi måste visa oss starka, men ni kan inte påverka oss egentligen.

När Siana och Hamid talar om framtiden görs återigen en åtskillnad mellan "vi" och "de". Ett stort ansvar läggs på "vi”, det vill säga ungdomar i Orten. Siana understryker att detta "vi" måste "sätta ner foten" och "visa oss starka". I sekvensen gestaltas ett slags dialog mellan Siana och Hamid som språkrör för Ortens ungdomar och ett outtalat "de". Båda frammanar en känsla av solidaritet och samhörighet bland "oss" - i relation till ett tänkt "dem”. Vilka dessa "de" är framgår egentligen inte, men det framgår tydligt att "ni kan inte påverka oss egentligen". Det är, framhåller Hamid, ungdomarna som är framtiden, som stakar ut framtiden. Siana och Hamid ger uttryck för en stark tilltro till att Ortens ungdomar kan åstadkomma förändring och kommer att göra det - "vi kan ... vi kommer ... vi ska". Framtiden har, såsom de beskriver det, i någon mening redan kommit, eftersom förändringar är i antågande: "vi har börjat för länge sen".

I ungdomarnas berättelser om framtiden finns ett återkommande konstaterande om att de kan förvänta sig större svårigheter och utmaningar än många andra, just på grund av vilka de är och var de bor, det vill säga på grund av sin tillhörighet och sitt hemmahörande i Orten. Denna beskrivning av framtiden och vad den förväntas ge är dock varken entydig eller hopplös, utan den rymmer både krassa beskrivningar av svårigheter och förhoppningar om förändring och möjligheter: 
MARA: Jag är en kvinna från Thailand, har inte svenskt efternamn, få kan uttala mitt efternamn och ingen kan stava det, jo några men, haha, men i alla fall så är jag från arbetarklass vilket jag ser, visst, några kämpar för jämställdhet och för jämlikhet, att invandare ska ha samma möjlighet, och några kämpar för klasserna, men jag befinner mig lägst i alla de tre kategorierna ... jag är lite rädd för framtiden, om det är tusen sökande och jag är en av dem, hur långt kommer jag komma? Det är lite ... det kan ju se lite mörkt ut, men jag hoppas att det blir bättre. Om man lever med den drömmen så att det finns fortfarande en chans.

Mara beskriver framtiden som både skrämmande och hoppfull. Den är inte antingen eller utan både och. Mara positionerar sig själv som "kvinna från Thailand" och "arbetarklass", som "lägst i alla de tre kategorierna". För henne, som befinner sig i denna utsatta position, kan framtiden te sig mörk. Villkoren är svåra för henne och dessutom svåra att förändra - "det kan ju se lite mörkt ut" - men inte omöjliga. Det som ändå gör framtiden hoppfull är att det fortfarande finns en chans. Det gäller att hoppas - och att vilja: hon hoppas att det ska bli bättre om hon lever med drömmen.

En snarlik, mångbottnad beskrivning av framtiden framträder också i samtalet mellan Siana och Younes:

SIANA: Det kommer vara uppdelat hela tiden, vart man än går, var man än är så är det uppdelat, så jag tror inte, jag vill inte låta negativ, men det kommer alltid finnas kvar känns det som, den här uppdelningen finns av en anledning men jag vet inte vad det är för en anledning, det är någonting mystiskt.

YOUNES: Personligen tror jag faktiskt det blir svårare för oss som bor här att lyckas, det blir svårare men det betyder inte att vi kommer ge upp, vi kommer fortsätta, det beror på också vilken bransch man funderar på att utbilda sig till. Om man ska bli någon ingenjör och någon från den rika delen av Stan söker jobbet och någon härifrån också söker jobbet, så tror jag självklart att det blir mycket svårare för oss att få det. Men det beror på vad man kollar efter också, var man bor, vad man har jobbat med tidigare, och så har man inte jobbat med någonting tidigare, haha, vilka språk man pratar, hur man ser ut ... nu för tiden vill de se en bild i ditt cv också, och jag tror det kommer försvåra faktiskt, så jag upplever inte något slags rättvisa i det om man säger så.

JAMES: Är man som boende här medveten om det här, alltså att det är på olika villkor som man konkurrerar?

YOUNES: Jag tror faktiskt det är så att alla redan vet om det och de som väljer att ta den vägen är villiga att offra ännu mer, de andra ger upp och väljer en annan väg där det är enklare, men det beror på som jag sa vilken bransch det är. 
Den bransch jag vill ta är lärarbranschen och där finns det hur mycket jobb som helst, men det beror på vilken bransch man väljer. Så det finns alltid hinder och jag tror det är fler hinder för oss, men man lyckas om man vill.

Beskrivningen av framtiden är återigen motsägelsefull. Å ena sidan kommer villkoren sannolikt att vara svåra. Uppdelningen i staden och mellan människor kommer sannolikt att bestå. De orättvisor som kan skönjas i dag kommer sannolikt att finns även i morgon. Dessa villkor beskrivs som så givna och självklara att de knappast behöver diskuteras: "det är så att alla redan vet om det". Varför situationen ser ut som den gör har dock ungdomarna svårt att ge något bra svar på. Det finns inga krafter som kan hållas ansvariga, ingen logik som går att begripa - "det är någonting mystiskt", som Siana uttrycker saken. Vad det nu än må vara som orsakar dessa ojämlikheter så ger å andra sidan framtiden möjligheter. Framtiden må vara oviss och svår, men det finns ändå en stark tilltro till att förändring är möjlig och att en sådan kommer att äga rum. För att åstadkomma förändring handlar det om att vilja och offra ännu mer: "man lyckas om man vill".

\section{"Det handlar om att engagera sig" - om politiskt och ideellt engagemang}

Frågan är då hur ungdomarna tänker sig att dessa förändringar ska komma till stånd och hur framtiden konkret ska stakas ut. Liksom berättelserna om tillvaron i Orten i dag bär ungdomarnas berättelser om framtiden för Orten på flera delvis motsägelsefulla inslag. Bland ungdomarna beskrivs kollektivt engagemang, politiskt och ideellt, som ett viktigt medel för att åstadkomma förändringar och forma framtiden. Sättet att tala om kollektivt engagemang är emellertid inte entydigt.

I en av intervjuerna åskådliggörs en närmast konfliktfylld hållning till kollektivt engagemang. Bland ungdomarna framträder inledningsvis en starkt skeptisk grundhållning till politik och politiskt engagemang.

JAMES: Tänker ni någon gång på politik?

JONATHAN: Alltså, jag hatar politik.

ÖVRIGA: Hahaha.

TERRY: Det där, jag har inget med det att göra, politiken. 
Politik beskrivs här som något som inte berör ungdomarna, särskilt inte Jonathan och Terry. När samtalet fortsätter förändras dock denna grundhållning och fler nyanser framträder, även hos Jonathan och Terry, som inledningsvis hört till de allra mest skeptiska.

MYNER: Politiken påverkar mycket, hur det ser ut i dag, men alltså jag vet inte, inte insatt i politiken.

JAMES: Är det för att ni inte är intresserade eller för att det inte känns som att det kommer göra någon skillnad?

MYNER: Det är för mycket att tänka på, alla de här partierna, alla har olika mål men är ändå likadana, så jag fattar inte.

TERRY: Ja.

SHAHIR: Jag håller med.

JONATHAN: Samma här.

JAMES: Hur kommer det sig för din del?

SHAHIR: Alltså, jag vet inte. Jag tycker om att bara kolla på fotboll, haha.

TERRY: Jag tror det är för att det inte påverkar oss så mycket eftersom vi fortfarande är unga.

MYNER: Jag får ändå inte rösta förrän nästa år.

JAMES: Kommer ni rösta när ni får det då?

TERRY: Det är femtio-femtio.

SHAHIR: Jag gjorde det.

JONATHAN: Det är viktigt att delta. Om SD vinner får våra föräldrar tagga.

TERRY: Ja, det är därför.

Sekvensen visar hur ungdomarnas argumentation om politik och politiskt engagemang inte grundar sig i endast en föreställning, utan i flera motstridiga föreställningar. Ungdomarna har ingen "färdig" uppfattning om politik och politiskt engagemang, utan deras uppfattningar är snarare i ständig omdaning. Av samtalet framgår att synen hos var och en av ungdomarna formas i och genom det samspel som äger rum i samtalet, utifrån de diskursiva resurser som samtalet erbjuder dem. Samtidigt som politik är ointressant och inte berör är det paradoxalt nog också oerhört betydelsefullt, inte minst med avseende på Sverigedemokraternas ökade valframgångar, som för Jonathan är huvudskälet till att rösta i nästkommande val: om de får makten kommer det att få drastiska konsekvenser inte bara för honom själv utan även för hans familj. Just detta uttalande fungerar som en diskursiv resurs som får den ursprungligen starkt skeptiske Terry ("Det där, jag har inget med det att göra, politiken") att till 
slut framhålla vikten av att rösta. Samtalet kan ses som ett exempel på hur motstridiga hållningar står mot varandra men att de i konkreta samtalssituationer kan fogas samman av dem som ingår i samtalet, i syfte att skapa förståelse för den aktuella situationen och de frågor som aktualiserats. Politisk skepsis utesluter här inte automatiskt politiskt engagemang. Sekvensen visar snarare på hur ungdomarna konkret skapar sin politiska hållning - utifrån de olika diskursiva resurser som uppkommit under samtalets gång.

I en annan intervju framkommer en starkare betoning av och tilltro till möjligheterna att engagera sig politiskt och ideellt:

SIANA: Alltså typ, jag tycker inte ens att man ska behöva tänka tanken och försöka ändra egentligen, men ja, det handlar om att engagera sig, absolut, för annars kommer vi ingen vart. Så här, skriva Facebook-statusar och sitta hemma och inte göra någonting, för så här, förändring händer inte över en dag. Det gäller att kämpa ... brinner man verkligen för någonting så ska man göra det man kan för att ändra bilden, genom vad som helst. Typ fotboll, bara genom fotboll kan man ändra bilden, engagera sig i något, parti, genom allt egentligen.

För Siana är det självklart att förändring kräver engagemang och hårt arbete. Förändring kommer inte till stånd ur intet. Den som vill åstadkomma något måste engagera sig och stå upp för sina ideal: "Det gäller att kämpa". Egentligen spelar det mindre roll hur detta engagemang kommer till uttryck. Det kan vara fråga om partipolitiskt arbete, men likaväl ideellt föreningsarbete. Siana framhåller för egen del just engagemang inom fotboll som en av många möjligheter när det gäller att skapa en bättre framtid för de uppväxande i Orten. Hon berättar att hon liksom Younes är fotbollstränare för tio- och elvaåringar från Orten, och båda beskriver detta engagemang som ett sätt att fungera som goda förebilder för barnen samtidigt som det utmanar omvärldens föreställningar om Orten:

JAMES: Hur kommer det sig att ni valt att engagera er på det sättet?

SIANA: Jag tänkte så här, du vet det här med att ändra bilden, det handlar om det också. Vi har så många talanger här i Orten. Det är helt otroligt. Men det är inte så att de i stan kommer in hit för att kolla på våra talanger. Så det gäller att vi bygger upp ... vi bjuder in dem om de inte kommer. Vi bjuder in dem igen, om de inte kommer då. Vi ger inte upp. Så det handlar om att prestera på det 
sättet också, du vet när man kommer hit. Vi är en stor familj. Alla från Orten är en stor familj.

YOUNES: För mig och Siana handlar det om barnen ... en tio-elvaåring kan inte åka kollektivt ända in till Stan för att träna med andra lag. I så fall är man tvungen att välja ett sämre lag och därför försöker vi utveckla det här laget. Det är mer att försöka få barnen att stanna här och inte åka till andra sidan.

SIANA: Sen också vi har ju spontanidrott också. Vi brukar öppna så här på kvällarna och det är då vi ger ungdomar en chans, och barnen, att komma och spela fotboll: vi finns här för er.

Vi kan här se hur Siana och Yuones i talet om ideellt engagemang använder sig av en rad diskursiva resurser. I sekvensen relaterar de till en samtida, väl etablerad diskurs om det ideella engagemangets och specifikt idrottens roll, potential och sociala nytta (jfr Ekholm 2016). Enligt denna diskurs antas ideellt engagemang - och specifikt idrotten - erbjuda meningsfull sysselsättning för de unga, ge chans till ett bättre liv samt bidra till att bryta omgivningens föreställningar. Inte minst uppges idrotten erbjuda en känsla av tillhörighet och gemenskap, återigen gestaltad med hjälp av familjemetaforen som diskursiv resurs: "vi är en stor familj". Enligt denna tankefigur kan idrotten på så sätt användas som ett medel för att skapa förutsättningar som ännu inte finns, det vill säga att skapa framtiden. Detta medel beskrivs som både konkret och lättillgängligt för dem som vill använda sig av det. Återigen åskådliggörs alltså en vilja till förändring och en förvissning om att förändring kommer att ske: det gäller bara att engagera sig.

\section{"Det är klart att skolan är viktig" - om utbildning och dess potential}

En annan återkommande berättelse om framtiden och hur framtiden kan skapas kretsar kring betydelsen av utbildning. I samtliga intervjuer beskrivs utbildning som en nödvändighet för att kunna skapa sig en framtid - oavsett om den kommer att utspelas i Orten eller någon annanstans:

HAMID: Det är klart att skolan är viktig. Man strävar ju efter nåt bättre än att bara hänga, så alltså, man har ett mål.

SIANA: Den blir viktig, alltså jag tycker så här att skolan blir viktig med tiden, typ nu, vill man söka ett arbete måste man ha en gymnasieexamen, ja men då måste jag klara av gymnasiet och sen får man se hur det går sen, det är viktigt men, jag vet inte vad jag tycker om skolan. 
YOUNES: Skolan är skolan. Jag tycker kunskap är viktigt, men skolan ... Det spelar ingen roll vart man får den kunskapen ifrån, men gymnasieexamen är viktig. Sen efter det ... så länge man har kunskap om det man vill göra. Man behöver inte läsa vidare egentligen.

Gymnasieutbildning beskrivs i denna sekvens som en viktig förutsättning för att kunna forma sin framtid, oavsett hur ungdomarna personligen ser på skolan. Gymnasieutbildningen gör det möjligt att hitta en meningsfull sysselsättning, "nåt bättre än att bara hänga", och beskrivs som ett krav för att hitta arbete - "vill man söka ett arbete måste man ha en gymnasieexamen". På frågan om vad ungdomarna gör om fem år, svarar de:

SIANA: Jag bor kvar.

HAMID: Jag bor fortfarande kvar här. Jag ska bli en bra polis.

YOUNES: Jag kommer självklart bo kvar. Jag vill bli lärare och vill utbilda barn här, så jag kommer alltid vara här.

Samtliga ser de sin framtid i Orten. För två av dem, Hamid och Younes, har fortsatt utbildning varit det som har tagit dem dit de vill - till ett yrke som polis respektive lärare. Betydelsen av skola och fortsatt utbildning lyfts också fram i följande sekvens, från en annan fokusgruppsintervju. Frågan om vad ungdomarna gör om fem år sätter igång följande dialog:

LISA: Då har jag gått ut gymnasiet för två år sedan eller ungefär, ja, jag bor kanske kvar här om de bygger bra bostäder, vilket de inte verkar så bra på. Kanske bor någon annanstans. Det är ju väldigt mycket som beror på situationen. Jag kanske pluggar, jag kanske jobbar, jag kanske är ute och reser. Jag har egentligen ingen femårsplan. Jag har knappt en ettårsplan.

DIMEN: Om fem år så ... troligtvis bor jag kvar hemma. För jag har inte kommit in i någon lägenhet än [alla skrattar]. Jag pluggar, till samhällsvetare. Jag kan lika gärna ... Eller i så fall kanske jag har studentlägenhet, i Lund eller Luleå ... alltså vad som helst. Mycket beror på så här just med skola, men om fem år så pluggar jag vidare till min dröm.

MARA: Du hade inga planer [Lisa], men jag har typ så här fem-tioårs-, femtonårs-, femtioårsplan, alltså jag fungerar typ så att jag sätter upp mål. Jag har redan vetat sen jag var tio vad jag vill plugga. Jag vill bli jurist och det har jag vetat länge. Och även om jag inte kommer in direkt så kommer jag kämpa för att komma in. Det kan ta fem-tio år. Det kan ta en termin. Inte fan vet jag. Jag försöker ju liksom. Så förhoppningsvis så kommer jag in ... så inom fem år 
så pluggar jag det. Jag vill absolut bo kvar i Orten för att jag har lärt mig älska Orten mer och mer med åren ... så här stolt över Orten [slår sig själv mot bröstet] och alltså jag kan bo östra, västra ... alltså det spelar ingen roll, men Orten är typ mitt hem och jag ser inte mig själv någon annanstans.

Medan Mara har en tämligen bestämd uppfattning om sin framtid som jurist och boende i Orten - är Lisa och Dimen mer osäkra. Oavsett om de har konkreta planer inför framtiden är dock utbildning en viktig del av ett tänkt framtidsscenario - i eller utanför Orten.

\section{Avslutande diskussion}

I skuggan av de dramatiska förortsbränder som på senare år rönt stor uppmärksamhet i offentlig debatt, har denna artikel kretsat kring vardagliga förhandlingar bland några av de ungdomar som bor och lever i Orten, ett av landets mångetniska förortsområden. Dessa förhandlingar kretsar på olika sätt kring tillhörighet och identitet i vad som ofta beskrivs som samhällets och stadens periferier.

Utifrån en analys av fokusgruppsintervjuer med ungdomar i Orten har vi i artikeln visat på förekomsten av en i huvudsak samstämmig tolkningsrepertoar i intervjuerna, som frammanar en bestämd förståelse av samtiden och livet i Orten. Denna förståelse av tillvaron i Orten här och nu tar form inte minst $\mathrm{i}$ ett slags kontrastverkan till vad som i intervjuerna träder fram som en dominerande diskurs om utanförskap och utanförskapsområden i det omgivande samhället, som inte minst beskrivs som förstärkt av massmediernas berättelser om förorten som en annorlunda och hotfull plats vid sidan av det svenska samhället. I ungdomarnas berättelser erbjuder denna dominerande diskurs en uppsättning diskursiva resurser, särskilt i form av åtskillnaden mellan "vi" och "de", innanför och utanför. I relation till det omgivande samhällets dominerande diskurs om utanförskap och utanförskapsområden framträder i samtliga fokusgruppsintervjuer Orten som en trygghetens plats, där ungdomarna känner sig hemmahörande. Enligt en återkommande metaforik beskrivs detta hem i termer av en familj, en tät och kärleksfull social gemenskap, som erbjuder den trygghet och den omsorg som det omgivande samhället inte förmår erbjuda. 
Denna tolkningsrepertoar om tillvaron i Orten här och nu formar även ungdomarnas förståelse av framtiden. Ungdomarnas berättelser om framtiden är inte entydiga, utan åskådliggör en rad spänningar. Med avstamp i ungdomarnas beskrivning av hur deras tillvaron i Orten ser ut i nuläget framträder framtiden som både svår och oviss, men samtidigt hoppfull. Ungdomarna ger i sitt berättande om framtiden uttryck för en stark vilja till förändring, en vilja att på olika sätt utmana både omgivningens diskurser om Orten och rådande sociala villkor. När ungdomarna talar om framtiden och hur förändring kan bli möjlig är det ett antal scenarier som återkommer: politiskt deltagande, engagemang inom föreningslivet - specifikt idrotten - samt utbildning.

I ungdomarnas berättelser om framtiden är det i allt väsentligt individuella scenarier riktade mot Orten som framträder, medan scenarier som bygger på kollektiv handling riktade mot världen utanför lyser med sin frånvaro. När det gäller politiskt deltagande finns det i intervjuerna ingen entydig argumentationslinje. Ungdomarna ställer sig inte odelat säkra till om de skulle vara beredda att engagera sig politiskt genom att rösta. Deras politiska hållning ter sig inte som färdig, utan den tycks snarare formas i och genom samtalets gång, utifrån de olika argument som ställs mot varandra. När det gäller ideellt engagemang beskrivs det i huvudsak som individuellt orienterat, byggt på eget ansvarstagande och en vilja att engagemang som ideellt arbetande tränare bli en god förebild för barnen i Orten. Även utbildning ter sig som ett primärt individuellt framtidsscenario, och oavsett om ungdomarna tänker sig yrken och karriärer i eller utanför Orten är målbilderna många och ofta svävande.

För samtliga dessa scenarier är det i allt väsentligt ungdomarna och Orten som står i förgrunden. Enligt en argumentationslinje som återkommer i intervjuerna är det upp till Ortens ungdomar att ta eget ansvar och stå upp för sig själva om en förändring ska bli möjlig. Detta sätt att beskriva scenarier inför framtiden framstår därmed som ett slags eko från en samtida utanförskapsdiskurs - där det är upp till förorten att själv åstadkomma förändring (jfr Dahlstedt 20I5). Förutom ungdomarna är det $\mathrm{i}$ intervjuerna över huvud taget en påtaglig frånvaro av andra aktörer som framträder, som ställs till svars eller som görs till måltavlor för eventuell kritik och organiserad, kollektiv handling. Det omgivande sam- 
hället, från vilket ungdomarna beskriver sig som exkluderade, förblir i intervjuerna en väsentligen konturlös kuliss.

Med hjälp av den diskurspsykologiska ansats som anlagts i denna artikel har vi kunnat visa på hur ungdomar är tänkande och argumenterande individer och hur deras tänkande och argumentation formas i de sammanhang de befinner sig i. Vi har kunnat visa på hur deras tänkande och argumentation inte är något som är hugget i sten, utan snarare något föränderligt och mångbottnat. Ungdomarna är varken aktiva eller passiva, uppgivna eller hoppfulla, utan både och. En sådan mer nyansrik bild av förortstillvaron, av ungdomarnas samtid och drömmar om framtiden, utgör ett viktigt bidrag till samhällsdebatten inte minst med tanke på de svartvita beskrivningar som inte sällan ges i offentliga diskurser om ungdomar i utanförskapsområden.

Vad ungdomarna sedan faktiskt gör i sina vardagliga liv och vilka framtida scenarier de faktiskt kommer att iscensätta, det är naturligtvis en annan fråga som får vara föremål för en annan studie. Men om vi verkligen ska ta ungdomarnas berättelser på allvar så pekar de på en annan mycket viktig sak, nämligen att en annan framtid är möjlig, även om rådande villkor ter sig både svåra och hindrande. Och om en annan framtid är möjliga att tänka, då är den också möjliga att realisera. Det är också viktigt att poängtera, inte minst i tider som dessa, när en annan framtid knappt är möjlig att ens tänka.

\section{Referenser}

Ambrose, Anna (2016) Att navigera på en lokal skolmarknad. Stockholm: Barn- och ungdomsvetenskapliga institutionen, Stockholms universitet.

Andersson, Roger, Bråmå, Åsa \& Hogdal, Jon (2009) Fattiga och rika - segregerad stad. Flyttningar och segregationens dynamik $i$ Göteborg 1990-2006. Göteborg: Göteborgs stad.

Andersson, Åsa (2003) Inte samma lika. Identifikationer hos tonärsflickor i en multietnisk stadsdel. Eslöv: Symposion.

Billig, Michael (1987) Arguing and thinking. A rhetorical approach to social psychology. Cambridge: Cambridge University Press.

Billig, Michael (I99I) Ideology and opinions. Studies in rhetorical psychology. London: Sage. Bunar, Nihad (2009) När marknaden kom till förorten. Lund: Studentlitteratur.

Dahlstedt, Magnus (2005) Reserverad demokrati. Representation i ett maingetniskt Sverige. Umeå: Boréa. 
Dahlstedt, Magnus (2009) Aktiveringens politik. Demokrati och medborgarskap för ett nytt millenium. Malmö: Liber.

Dahlstedt, Magnus (2015) "Discourses of employment and inclusion in Sweden", i Righard, Erica m.fl. (red.) Social transformation in Scandinavian cities. Lund: Nordic Academic Press.

Dahlstedt, Magnus m.fl. (red.) (20I6) Utbildning, arbete, medborgarskap. Strategier för social inkludering $i$ den mångetniska staden. Umeå: Boréa.

Davidsson, Tobias (20I0) "Utanförskapelsen", Socialvetenskaplig tidskrift, I7, 2, s. I49-169. de los Reyes, Paulina m.fl. (20I4) "Bilen brinner ... men problemen är kvar". Berättelser om om Husbyhändelserna $i$ maj 2013. Stockholm: Stockholmia förlag.

Duits, Linda (2008) Multi-girl culture. An ethnography of doing identity. Amsterdam: Amsterdam University Press.

Edwards, Derek \& Potter, Jonathan (1992) Discursive psychology. London: Sage.

Ekholm, David (2016) Sport as a means of responding to social problems. Institutionen för samhälls- och välfärdsstudier, Linköpings universitet.

Ericsson, Urban (2007) Belägrade människor - belägrade rum. Om invandrargöranden och förorter. Institutionen för kulturantropologi och etnologi, Uppsala universitet.

Gergen, Kenneth J. (1985) "The social constructionist movement in modern psychology", American Psychologist, 40, 3, s. 266-275.

DoI: https://doi.org/I0.I037/0003-066X.40.3.266

Jackson, Richard \& Hall, Gareth (20I6) "Talking about terrorism: A study of vernacular discourse", Politics, 36, 3, s. 292-307. DoI: https://doi.org/I0.1177/026339571561079I

Kallstenius, Jenny (20I0) De mångkulturella innerstadsskolorna. Sociologiska institutionen, Stockholms universitet.

Kings, Lisa (20II) Till det lokalas försvar. Civilsambället $i$ den urbana periferin. Lund: Arkiv.

Kings, Lisa (20I4) "Förortens organisationer och kampen för förnyelse", i Fokus I4. Om ungas fritid och organisering. Stockholm: Myndigheten för ungdoms- och civilsamhällesstudier.

Lalander, Philip (2009) Respekt. Gatukultur, ny etnicitet och droger. Malmö: Liber.

Larsson, Jennie K. (2015) Integrationen och arbetets marknad. Stockholm: Atlas.

León Rosales, René (20IO) Vid framtidens hitersta gräns. Om maskulina elevpositioner i en multietnisk skola. Botkyrka: Mångkulturellt centrum.

León Rosales, René \& Ålund, Aleksandra (20I7) "Renaissance from the margins. Urban youth activism in Sweden", i Ålund, Aleksandra, Schierup, Carl-Ulrik \& Neergaard, Anders (red.) Reimagineering the nation. Essays on twenty-first-century Sweden. Frankfurt am Main: Peter Lang.

Lindbäck, Jonas \& Sernhede, Ove (2010) "Det 'integrerade' gymnasiet och den segregerade staden", Utbildning \& Demokrati, I9 I, s. II5-I4O.

Lundqvist, Catarina (2010) Möjligheternas horisont. Etnicitet, utbildning och arbete i ungas berättelser om karriärer. Institutionen för samhälls- och välfärdsstudier, Linköpings universitet. 
Morgan, Richard A. (red.) (1998) Focus group kit, vol. I, The focus group guidebook. Thousand Oaks: Sage.

Nortio, Emma m.fl. (2016) "Interpretative repertoires of multiculturalism - supporting and challenging hierarchical intergroup relations", Journal of Social and Political Psychology, 4, 2, s. 623-645.

DoI: https://doi.org/I0.5964/jspp.v4i2.639

Pripp, Oscar (2002) "Mediabilder och levd erfarenhet", i Ramberg, Ingrid \& Pripp, Oscar (red.) Fittja, världen och vardagen. Tumba: Mångkulturellt centrum.

Ristilammi, Per-Markku (1994) Rosengård och den svarta poesin. En studie i modern annorlundahet. Stehag: Symposion.

Scarpa, Simone (2015) The spatial manifestation of inequality. Institutionen för socialt arbete, Linnéuniversitetet.

Schierup, Carl-Ulrik, Ålund, Aleksandra \& Kings, Lisa (20I4) "Reading the Stockholm riots - a moment for social justice?", Race \& Class, 55, 3, s. I-2I.

DoI: https://doi.org/IO.II77/030639681350919I

Sernhede, Ove (2002) Alienation is my nation. Hiphop och unga mäns utanförskap i det nya Sverige. Stockholm: Ordfront.

Sernhede, Ove (20II) "School, youth culture and territorial stigmatization in Swedish metropolitan districts", Young, 19, 2, s. 159-180. DOI: https://doi.org/IO.II77/IIO33088IOoI900203

Sernhede, Ove \& Söderman, Johan (2010) Planet hiphop. Malmö: Liber.

Stigendal, Mikael (2016) Samhällsgränser. Ojämlikhetens orsaker och framtidsmöjligheterna $i$ en storstad som Malmö. Stockholm: Liber.

Tedros, Adiam (2008) Utanför storstaden. Konkurrerande framställningar av förorten $i$ svensk storstadspolitik. Förvaltningshögskolan, Göteborgs universitet.

Wetherell, Margaret (200I) "Themes in discourse research", i Wetherell, Margaret m.fl. (red.) Discourse theory and practice. A reader. London: Sage.

Wetherell, Margaret (2004) "Racism and the analysis of cultural resources in interviews", i Berg, Harry van den m.fl. (red.) Analyzing race talk. Multidisciplinary perspectives on the research interview. Cambridge: Cambridge University Press.

Wetherell, Margaret \& Edley, Nigel (2014) "A discursive psychological framework for analyzing men and masculinities", Psychology of Men \& Masculinity, I5, 4, s. 355-364. DOI: http://dx.doi.org/IO.I037/aoo37148

Wetherell, Margaret \& Potter, Jonathan (1988) "Discourse analysis and the identification of interpretive repertoires", i Antaki, Charles (red.) Analysing everyday explanation. A casebook of methods. Newbury Park: Sage.

Wetherell, Margaret \& Potter, Jonathan (1992) Mapping the language of racism. Discourse and the legitimation of exploitation. New York: Columbia University Press.

Wibeck, Victoria (2010) Fokusgrupper. Om fokuserade gruppintervjuer som undersökningsmetod. Lund: Studentlitteratur.

Ålund, Aleksandra (1997) Multikultiungdom. Kön, etnicitet, identitet. Lund: Studentlitteratur. 


\section{Moderna klassiker}

\section{Norbert Elias}

John L. Scotson

\section{Etablerade och outsiders}

\section{Arkiv förlag}

Norbert Elias (1897-I990) var en av I900-talets mest betydande sociologer. I Etablerade och outsiders (nu tillgänglig i en andra utvidgad upplaga) visar han på ett fascinerande sätt hur moralisk stigmatisering är en allmänt förekommande maktteknik varhelst det finns en konflikt mellan en etablerad och dominerande grupp och en underordnad, dominerad grupp; mellan bofasta och invandrare, vita och svarta i USA, högkastiga och kastlösa indier, män och kvinnor, välbeställda och fattiga.

Övers. Anita Sandberg \& Gunnar Sandin, 296 sidor 